\title{
Indywidualizacja a system w postępowaniu penitencjarnym w świetle kodeksu karnego wykonawczego
}

\section{DOROTA RONDALSKA}

ORCID: 0000-0003-2165-6263

Zakład Penitencjarystyki

Wydział Nauk Edukacyjnych Uniwersytetu im. Adama Mickiewicza w Poznaniu

Jeśli sięgnąć do słownika języka polskiego, to pod określeniem indywidualizacja znajdziemy definicję, zgodnie z którą jest to proces kształtowania się cech indywidualnych (osobniczych) jednostki lub zbiorowości. W takim kontekście można mówić zarówno o indywidualizacji poszczególnych ludzi, jak i społeczeństw, wspólnoty itp. ${ }^{1}$ Indywidualizacja zawarta w tytule artykułu ma jednak nieco inne znaczenie, bardziej rozbudowane. Oznacza bowiem zarówno sposób postępowania z osobami pozbawionymi wolności, jak i ustawową zasadę pracy penitencjarnej, nakazującą dostosowywać oddziaływania podejmowane w zakładzie karnym do każdego osadzonego, ściślej — do jego cech osobowych i specyfiki jego przypadku.

W warstwie standardów penitencjarnych indywidualizacja postępowania $\mathrm{z}$ osobami pozbawionymi wolności jest, przynajmniej w kontekście formalnym i normatywnym, niekwestionowanym jego priorytetem. Warto jednak zauważyć, że w piśmiennictwie polskim wiąże się ją na ogół z oddziaływaniem resocjalizacyjnym. Nie jest to pogląd do końca

1 Por. Słownik języka polskiego, t. 1, red. M. Szymczak, Warszawa 2010, s. 786. Nowa Kodyfikacja Prawa Karnego 54, 2019

(C) for this edition by CNS 
trafny, jako że resocjalizacja jest tylko fragmentem szerzej rozumianej pracy penitencjarnej. Pod tym ostatnim pojęciem należy bowiem rozumieć całokształt oddziaływań na skazanego osadzonego w zakładzie karnym bądź też areszcie śledczym. Na taki wniosek pozwala też analiza legalnej jej definicji, zgodnie z którą chodzi tu o oddziaływania penitencjarne, rozumiane jako zespół stosowanych w zakładzie środków i metod zmierzających do wzbudzenia w skazanym woli współdziałania w kształtowaniu jego społecznie pożądanych postaw ${ }^{2}$.

Ponieważ indywidualizacja w postępowaniu ze skazanym jest jednym z podstawowych standardów wykonywania kary pozbawienia wolności, warto podyskutować o regulacjach, które jej dotyczą, zawartych w kodeksie karnym wykonawczym, a także ocenić, w jakim stopniu ją rzeczywiście gwarantują. W tym celu należy przeanalizować nie tylko sposób formalnego sformułowania samej zasady, lecz także kodeksowe instrumentarium, służące jej realizacji.

Przechodząc do rozważań w tym zakresie, na początek kilka uwag o zasadach postępowania karnego, to znaczy dyrektyw określających jego sposób i charakter. Innymi słowy chodzi o szerzej ujmowane ustawowe gwarancje możliwości podejmowania indywidualizacji oddziaływań, mające na celu ukształtowanie pożądanych indywidualnych cech osób odbywających karę pozbawienia wolności w zakładzie karnym.

Jest z tym jednak pewien problem, albowiem problematyka tych zasad jest stosunkowo słabo dostrzegana przez polski kodeks karny wykonawczy ${ }^{3}$. Zdaniem Z. Hołdy wiąże się to z brakiem opracowania zasad postępowania wykonawczego przez naukę prawa karnego wykonawczego $^{4}$. Widać to w różnych próbach omówienia czy też komentarza do tych zasad. Dla przykładu, S. Pawela odwołuje się do zasad wspólnych postępowania karnego oraz prawa karnego wykonawczego (humanizmu, praworządności, sprawiedliwości, prawdy materialnej, kontradyktoryjności, współdziałania ze społeczeństwem). Wskazuje co prawda na zasady charakterystyczne tylko dla prawa karnego wykonawczego (na przy-

2 Rozporządzenie Ministra Sprawiedliwości z dnia 14 sierpnia 2003 roku w sprawie sposobów prowadzenia oddziaływań penitencjarnych w zakładach karnych i aresztach śledczych, Dz.U. Nr 151 z 2003 r., poz. 1468.

3 S. Pawela, Prawo karne wykonawcze, Kraków 2003, s. 79; J. Hołda, Z. Hołda, Prawo karne wykonawcze, Kraków 2004, s. 79.

Nowa Kodyfikacja Prawa Karnego ${ }^{4}$ 54, 2019

(C) for this edition by CNS 
kład modyfikowania kar i środków, podporządkowania sądowi procesu wykonania orzeczeń $)^{5}$, jednak ma świadomość, że stopień wykorzystania ich w procesie wykonania kary pozbawienia wolności jest niewielki. Albowiem jeśli do indywidualizacji odnieść zasadę modyfikacji kar i środków, to kodeksowe możliwości takiej modyfikacji są bardzo ograniczone. Wskazywane tu zasady mają poza tym charakter ogólny i jako takie tworzą raczej podstawę aksjologiczną systemu prawa karnego wykonawczego niż konkretne dyrektywy wykonywania kary pozbawienia wolności. Z ostatnich prób sformułowania zasad odnoszących się do tego warto wskazać opracowanie T. Szymanowskiego ${ }^{6}$.

W takiej sytuacji w celu zrekonstruowania zasady indywidualizacji należy sięgnąć do tekstu kodeksu karnego wykonawczego. Pierwszy przepis, na który trzeba zwrócić uwagę, to art. $67 \S 1$ tego kodeksu. Zgodnie z nim ,wykonanie kary ma celu wzbudzanie w skazanym woli współdziałania w kształtowaniu jego społecznie pożądanych postaw, w szczególności poczucia odpowiedzialności oraz potrzeby przestrzegania porządku prawnego i tym samym powstrzymania się od powrotu do przestępstwa". Chodzi tu zatem o poprawę skazanego, a więc cel szczególnoprewencyjny. Uzupełnieniem tego przepisu jest artykuł $73 \S 1$ k.k.w., który poza tym celem przywołuje wzgląd na ochronę społeczeństwa.

W jaki sposób osiągnąć rzeczoną poprawę skazanego, wskazują z kolei § 2 i 3 przepisu art. 67 k.k.w. Pierwszy z nich przewiduje prowadzenie zindywidualizowanego oddziaływania na skazanych $\mathrm{w}$ ramach określonych w ustawie systemów wykonywania kary, w różnych rodzajach i typach zakładów karnych. Drugi zaś uszczegóławia, że w oddziaływaniu na skazanych uwzględnia się przede wszystkim pracę, szczególnie taką, która sprzyja uzyskaniu odpowiednich kwalifikacji zawodowych, nauczanie, zajęcia kulturalno-oświatowe i sportowe, nadto podtrzymywanie kontaktów z rodziną i światem zewnętrznym oraz środki terapeutyczne.

Już pobieżna analiza wskazanych przepisów pozwala zauważyć pewną sprzeczność. Mianowicie w $§ 2$ mowa jest o indywidualizacji w ramach systemu. Z kolei treść $§ 3$ skłania do postawienia pytania o to,

5 Określenie według S. Paweli, op. cit., s. 83.

6 T. Szymanowski, Polityka penitencjarna w Polsce współczesnej, [w:] System prawa karnego, red. A.Marek, Warszawa 2010, s. 266-313.

Nowa Kodyfikacja Prawa Karnego 54, 2019

(C) for this edition by CNS 
czy standardowe środki oddziaływania penitencjarnego, takie jak praca, nauka, zajęcia kulturalno-oświatowe itp., mogą służyć oddziaływaniu indywidualnemu, a więc zróżnicowanemu. Przecież środki te stosuje się do określonych prawem grup skazanych (na przykład młodocianych, recydywistów penitencjarnych, skazanych objętych programowanym oddziaływaniem). W ten sposób jednak indywidualizacja oddziaływań nabiera cech oddziaływania na określone zbiorowości.

Podejmując owe kwestie, warto przypomnieć opinię S. Lelentala, który stwierdza, że polskie ustawodawstwo wykonawcze posługuje się terminem ,,indywidualizacja” tylko w odniesieniu do jej form instytucjonalnych ${ }^{7}$. Jego zdaniem jest ona realizowana w ramach wyznaczonych przez kodeks karny wykonawczy oraz regulamin wykonania kary pozbawienia wolności. Ich unormowania określają więc system wykonania kary (art. 81 k.k.w.), rodzaj i typ zakładu karnego (art. 69 k.k.w. oraz art. 70 k.k.w.), ponadto klasyfikację skazanych ${ }^{8}$. W praktyce prowadzi to do urzędowego podziału ogólnej populacji osadzonych na różne kategorie, inaczej grupy, a także na obejmowaniu tych grup oddziaływaniami systemowymi.

Jeśli przypomnieć, że we wstępie artykułu powołałam słownikową definicję indywidualizacji, zgodnie z którą jest to proces kształtowania się cech indywidualnych (osobniczych) jednostki lub zbiorowości, to zasada indywidualizacji w trakcie wykonania kary pozbawienia wolności byłaby w takim działaniu respektowana. Uzasadnienie takiej oceny można znaleźć w treści art. 67 § 2 k.k.w.: „dla osiągnięcia celu określonego $\mathrm{w} \S 1$ prowadzi się zindywidualizowane oddziaływanie na skazanych w ramach określonych w ustawie systemów wykonywania kary, w różnych rodzajach i typach zakładów karnych".

W dalszym ciągu moich rozważań podejmę analizę koherencji między pojęciami indywidualizacji oddziaływań a oddziaływań w ramach systemów wykonawczych, realizowanych w różnych rodzajach oraz typach zakładów karnych. Należy się jednak uwaga, że „system wykonawczy” jest określeniem nieco innym niż określenie „oddziaływania systemowe", a więc podejmowane w ramach systemu penitencjarnego. O ile można bowiem wyobrazić sobie zindywidualizowanie pracy peni-

7 S. Lelental, Prawo karne wykonawcze, Warszawa 1990, s. 318.

8 Ibidem, s. 317.

Nowa Kodyfikacja Prawa Karnego 54, 2019

(C) for this edition by CNS 
tencjarnej ze skazanym w ramach określonego systemu wykonania kary pozbawienia wolności, o tyle oddziaływanie systemowe oznacza akcje ogólne, zbiorcze, podejmowane wobec całej populacji penitencjarnej.

Rozumowanie tu przedstawione prowadziłoby do wniosku, że zasada indywidualizacji w postaci ujętej w kodeksie karnym wykonawczym rozkłada się niejako na dwa poziomy oddziaływań. Pierwszy z nich to poziom oddziaływań grupowych, na którym wyodrębnia się z całej zbiorowości zakładu karnego określone grupy osadzonych. Kryterium doboru byłoby tu zakwalifikowanie ich do określonego systemu wykonania kary pozbawienia wolności. Drugi, indywidualny, to poziom, w ramach którego z wyłonionych wcześniej określonych grup dobiera się poszczególne osoby i tylko te poddaje oddziaływaniom indywidualnym. Zagadnienie to wymaga dokładniejszego omówienia, jako że w doktrynie prawa karnego wykonawczego ocenia się często, iż systemy wykonania kary pozbawienia wolności są jednym z niezwykle istotnych czynników indywidualizacji oddziaływania na skazanych. Wynika z tego, że istnieje tu wyraźny funkcjonalny związek ${ }^{9}$.

Powszechnie uważa się, że systemy wykonawcze są obecnie jedną z podstawowych instytucji polskiego prawa wykonawczego. Ich wprowadzenie jest efektem postępowych zmian w ustawodawstwie karnym wykonawczym po roku 1989. Co oznacza zatem to pojęcie, na czym polega ich koncepcja.

Zdefiniowanie tego pojęcia w sposób możliwy do zaakceptowania przez wszystkich nie jest łatwe. Przegląd unormowań w międzynarodowych aktach prawnych dotyczących kary pozbawienia wolności pokazuje bowiem, że go w nich nie ma. Jeśli akty te posługują się pojęciem systemu, to najczęściej w kontekście ogólnym. Reguła 1 Reguł Mandeli ONZ z roku $2015^{10}$ podaje na przykład, że nie mają one na celu szczegółowego opisania wzorcowego systemu rozwiązań dotyczących instytucji o charakterze izolacyjnym. Dążą jedynie, na podstawie powszechnie

9 S. Pawela, op. cit., s. 183.

${ }^{10}$ N. Mandela był długoletnim więźniem systemu opartego na apartheidzie w Republice Południowej Afryki, walczył o prawa człowieka. Dla jego uczczenia w dniu 7 października 2015 roku. Zgromadzenie Ogólne ONZ przyjęte Standardy ONZ Minimum Traktowania Więźniów nazwało Regułami Nelsona Mandeli. Są one zaktualizowaną wersją Wzorcowych Reguł ONZ Traktowania Więźniów z 1955 roku, których głównym celem jest poprawa sytuacji więźniów na świecie.

Nowa Kodyfikacja Prawa Karnego 54, 2019

(C) for this edition by CNS 
akceptowanych współczesnych poglądów oraz zasadniczych elementów najbardziej odpowiednich spośród istniejących obecnie systemów, do ustalenia tego, co jest powszechnie uznawane za właściwości zasady i praktyka postępowania z więźniami oraz zarządzania instytucjami o charakterze izolacyjnym ${ }^{11}$. Jak zatem widać, pojęciem systemu oznaczono w nich zespół elementów wzajemnie powiązanych w układy oraz realizujących jako całość funkcję nadrzędną, to jest odizolowanie określonych osób od społeczeństwa. W takim znaczeniu chodzi tu o kompleks czy też całokształt określonych rozwiązań.

Jeśli zatem to uwzględnić, wówczas można stwierdzić, że polska myśl penitencjarna używa pojęcia „system” w dwóch znaczeniach. Pierwsze z nich oznacza system penitencjarny, drugie system wykonania kary. W pierwszym znaczeniu S. Lelental ${ }^{12}$ definiuje system penitencjarny jako całokształt rozwiązań prawnych i organizacyjnych, zwłaszcza w zakresie zarządzania zakładami karnymi oraz ich personelem, umożliwiających wykonanie bezwarunkowej kary pozbawienia wolności, jak również określających sposób postępowania z więźniami.

W kwestii rozważań nad koherencją indywidualizacji oddziaływań do oddziaływań systemowych ta definicja jest jednak mało przydatna. Potrzebne jest bowiem zdefiniowanie systemu w drugim ze wskazanych znaczeń, a więc w odniesieniu do logiki oraz metodycznych dyrektyw wykonawczych.

W znanym komentarzu do kodeksu karnego wykonawczego S. Lelentala ${ }^{13}$ takiej definicji systemu brakuje. Nie podają jej też inne komentarze $^{14}$ i prace zbiorowe ${ }^{15}$. Legalnej definicji systemu wykonawczego nie zamieszczono więc i w kodeksie karnym wykonawczym (por. art. 81 k.k.w.). Wynika z tego wniosek, że polska penitencjarystyka pojęciem systemu posługuje się na wyczucie. Wobec tego do dalszej analizy

11 Wzorcowe Reguły Minimalne Organizacji Narodków Zjednoczonych zob. https:/www.rpo.gov.pl/sites/default/files/Reguly_Mandeli.pdf (dostęp: 18.01.2020).

12 S. Lelental, Prawo karne..., s. 133.

13 S. Lelental, Kodeks karny wykonawczy. Komentarz, Warszawa 2010.

14 Np. Z. Hołda, K. Postulski, Kodeks karny wykonawczy. Komentarz, Gdańsk 2005; S. Pawela, Kodeks karny wykonawczy. Praktyczny komentarz z indeksem rzeczowym, Warszawa 1999; Kodeks karny wykonawczy. Komentarz, red. J. Lachowski, Warszawa 2016.

15 Np. System penitencjarny i postpenitencjarny $w$ Polsce, red. T. Bulenda, R. Musidłowski, Warszawa 2003.

Nowa Kodyfikacja Prawa Karnego 54, 2019

(C) for this edition by CNS 
należy przyjąć, że chodzi tu o taki zespół środków i metod oddziaływania na skazanych, który zapewnia ich dostosowanie do osobowości skazanego i celu wykonania kary pozbawienia wolności ${ }^{16}$. Jak widać, to ujęcie pozwala powiązać system wykonawczy z zasadą indywidualizacji wykonania kary pozbawienia wolności. Przemawia za tym także i to, że w ramach systemu programowanego oddziaływania, chociaż tylko w nim, układa się indywidualne programy oddziaływania z tymi ze skazanych, którzy wyrażą wolę współuczestniczenia w nich bądź są do tego zobowiązani (na przykład młodocianymi). Programy takie są zatem programami systemowymi, cechuje je pewna schematyczność i powtarzalność.

Celem zakwalifikowania określonych grup (zbiorowości) skazanych do konkretnego systemu wykonawczego jest dostosowanie warunków i sposobu wykonania kary do wystandaryzowanych cech więźniów z tych grup, odbywających karę pozbawienia wolności, a także stopnia zagrożenia, jakie mogą stworzyć, bądź nie, dla zakładu karnego. W przypadku systemu programowanego oddziaływania jest to także wzgląd na możliwości oddziaływania resocjalizacyjnego. Jak zauważa między innymi S. Pawela, jego podjęcie ma na względzie wzbudzenie indywidualnej, pozytywnej motywacji do działalności społecznie użytecznej i zmiany dotychczasowego, wadliwego, modelu życia. Aby to umożliwić, zakład karny musi zapewnić skazanemu warunki do rozwijania form aktywności, ważnych i potrzebnych po jego opuszczeniu, musi także stworzyć atmosferę normalnego środowiska społecznego ${ }^{17}$. Środkiem do osiągnięcia tego celu ma zatem być instytucjonalna indywidualizacja oddziaływań penitencjarnych (różne rodzaje i typy zakładów karnych, klasyfikacja skazanych, system progresji, a także dopuszczalność modyfikowania kar i środków w sądowym postępowaniu wykonawczym).

Tak rozumianą indywidualizację oddziaływań można odtworzyć na podstawie wykładni systemowej odpowiednich przepisów kodeksu karnego wykonawczego. Jest ona ponadto unormowana w rozdziale X oddziale 3 pt. Wykonanie kary i jej indywidualizacja. Zdaniem S. Lelentala tytuł ten nie może być odczytany tak, że tylko przepisy umieszczone w tym rozdziale stanowią o unormowaniach konkretyzujących treść za-

16 Por. P. Wierzbicki, Indywidualizacja penitencjarna $w$ Polsce, Warszawa 1976, s. 18 .

17 S. Pawela, Prawo karne wykonawcze..., s. 184.

Nowa Kodyfikacja Prawa Karnego 54, 2019

(C) for this edition by CNS 
sady indywidualizacji wykonania kary pozbawienia wolności. Dotyczą jej bowiem, wprawdzie w różnym stopniu, wszystkie przepisy rozdziału X k.k.w. ${ }^{18} \mathrm{Z}$ takim stanowiskiem można zgodzić się tylko częściowo. Trudno zakwalifikować bowiem do nich na przykład unormowania oddziału 10 pt. Odroczenie i przerwa wykonania kary pozbawienia wolności czy też oddziału 13 pt. Informowanie o opuszczeniu przez skazanego zakładu karnego. Zawierają one raczej wskazówki dla sądu lub też przesłanki materialne, które ma on uwzględniać przy stosowaniu tych instytucji, nakładają określone obowiązki na organy postępowania wykonawczego (na przykład sędziego penitencjarnego, dyrektora zakładu karnego) bądź też określają prawa ofiar przestępstwa w zakresie wzmożenia ich bezpieczeństwa. Gwoli poparcia takiego wniosku warto przytoczyć w całości treść art. 168a § 1 k.k.w. (oddział 13):

na wniosek pokrzywdzonego, odpowiednio, sędzia penitencjarny lub dyrektor zakładu karnego niezwłocznie zawiadamia pokrzywdzonego, jego przedstawiciela ustawowego lub osobę, pod której stałą pieczą pokrzywdzony pozostaje, o zwolnieniu skazanego z zakładu karnego po odbyciu kary, o ucieczce skazanego z zakładu karnego, a także o wydaniu decyzji o udzieleniu skazanemu:

1) przepustki, o której mowa w art. 91 pkt 7 i art. 92 pkt 9;

2) czasowego zezwolenia na opuszczenie zakładu karnego bez dozoru lub bez konwoju funkcjonariusza Służby Więziennej albo asysty innej osoby godnej zaufania, o którym mowa w art. $138 \S 1$ pkt 7 lub 8, art. 141a $\S 1$, art. $165 \S 2$ oraz art. $234 \S 2$;

3) przerwy w wykonaniu kary;

4) warunkowego zwolnienia.

W kontekście moich rozważań wskazać jednak trzeba na inną jeszcze, ważniejszą kwestię. Jest ona istotniejsza od formalnego sposobu legislacji zasady indywidualizacji w kodeksie karnym wykonawczym. Dotyczy bowiem jej wymiaru materialnego. Chodzi o to, że tytuł oddziału 13 nie jest do końca jasny. Jego analiza skłania do postawienia pytania, czy pojęcie indywidualizacji odniesiono w nim do procesu wykonawczego, czy też do samej kary. Inaczej mówiąc, powstaje wątpliwość, czy chodzi tu o indywidualizację wykonania kary, czy raczej samej kary. Nie jest to przecież to samo. Wykładnia gramatyczna tego tytułu skłania raczej ku drugiemu ze wskazanych odniesień, co zmienia w istotny sposób kontekst dyskusji o zasadzie indywidualizacji w kodeksie karnym wyko-

18 S. Lelental, Kodeks karny wykonawczy. Komentarz, Warszawa 2017, s. 366.

Nowa Kodyfikacja Prawa Karnego 54, 2019

(C) for this edition by CNS 
nawczym. Cytowany już S. Pawela ${ }^{19}$ pisze o zasadzie indywidualizacji wykonania kary pozbawienia wolności. Podaje jednak, że została ona „wysłowiona” nie w oddziale 3 k.k.w., lecz w art. $67 \S 2$ tego kodeksu ${ }^{20}$. Powstaje zatem pytanie, jak ma się sformułowanie tego przepisu zredagowane jako ,zindywidualizowane oddziaływanie na skazanych w ramach określonych w ustawie systemów wykonywania kary, w różnych rodzajach i typach zakładów karnych" do sformułowania w tytule oddziału 13: „wykonanie kary i jej indywidualizacja”, które zgodnie z zasadami logiki należy odczytać jako indywidualizacja kary. Indywidualizacja kary jest jednak pojęciem prawa karnego materialnego, a więc kodeksu karnego.

$\mathrm{O}$ zasadzie indywidualizacji kary w takim rozumieniu wspomina między innymi jeden z twórców tego kodeksu — A. Marek. Według niego odnosi się ona do kary i środków karnych. Polega „na ich dostosowaniu do indywidualnych właściwości i warunków osobistych sprawcy oraz możliwości i perspektyw zapobiegawczego i wychowawczego oddziaływania na niego"21. Wynika z tego, że indywidualizacja kary jest zasadą jej sądowego wymiaru. Autor ten pisze, że oznacza ona też, iż okoliczności wpływające na wymiar kary uwzględnia się tylko co do tej osoby, której one dotyczą (art. 55 kodeksu karnego) ${ }^{22}$. Jeśli zatem oprzeć się na tych uwagach, to można postawić wniosek, że tytuł oddziału 3 sformułowano błędnie. Pomieszano bowiem zagadnienia prawa karnego wykonawczego z zagadnieniami prawa materialnego. Dalsza analiza treści tego oddziału zasygnalizowane wątpliwości pogłębia.

Po pierwsze, jego unormowania dotyczą tylko zagadnień wykonawczych i to o charakterze technicznym, mających z indywidualnymi oddziaływaniami penitencjarnymi niewiele wspólnego. Po wtóre, określają cechy zakładów karnych, a także cechy i zasady stosowania systemów wykonawczych, kwalifikacji skazanych itp., co nie dotyczy wymiaru kary. W oddziale tym mowa jest bowiem o osobach, które wymiar kary mają już za sobą, a więc skazanych.

Warto te uwagi rozwinąć bardziej. Szczegółowe przepisy zawarte w oddziale 3 odnoszą się najpierw do kwestii proceduralnych, związanych

19 S. Pawela, Prawo karne wykonawcze..., s. 228.

20 Ibidem, s. 229.

21 A. Marek, Prawo karne, Warszawa 2010, s. 329.

22 Ibidem.

Nowa Kodyfikacja Prawa Karnego 54, 2019

(C) for this edition by CNS 
z umieszczeniem skazanego z zakładzie karnym. Mianowicie, art. $79 \S 1$ k.k.w. stanowi, że sąd wzywa go do stawienia się w wyznaczonym terminie $\mathrm{w}$ areszcie śledczym, położonym najbliżej miejsca jego stałego pobytu, wraz z dokumentem stwierdzającym tożsamość. Sąd może też polecić doprowadzenie skazanego do aresztu śledczego bez wezwania. Inny przepis oddziału 3 normuje z kolei kwestie związane z potwierdzeniem jego tożsamości przy przyjmowaniu do aresztu śledczego. Musi on zatem okazać dokument potwierdzający tę tożsamość, podać dane osobowe oraz dane o miejscu stałego pobytu, uprzedniej karalności i stanie zdrowia, ponadto o ciążącym na nim obowiązku alimentacyjnym. Skazany może być także poddany czynnościom służacym jego identyfikacji, w szczególności: sfotografowaniu, oględzinom zewnętrznym ciała, pobraniu odcisków palców oraz okazaniu innym osobom (art. 79a $\S 1$ k.k.w.). Wreszcie, przekazuje on do depozytu dokumenty, pieniądze, przedmioty wartościowe oraz inne przedmioty, których nie może mieć w celi (§ 2). Czynności te dotyczą wszystkich przyjmowanych do zakładów karnych. Są więc schematyczne i rutynowe, trudno w nich doszukiwać się indywidualizacji postępowania.

Podobny charakter mają inne jeszcze czynności o charakterze wstępnym, związane z procedurą osadzenia. Określa je także oddział 3 kodeksu karnego wykonawczego. Mają one charakter adaptacyjny do warunków więzienia. Ich przykładem może być umieszczenie osoby nowo osadzonej $\mathrm{w}$ jednostce penitencjarnej w celi przejściowej. Zasady takiego umieszczenia reguluje art. 79b $§ 1$ k.k.w., zgodnie z którym skazanego przyjętego do aresztu śledczego umieszcza się w celi przejściowej na okres niezbędny, nie dłużej jednak niż na 14 dni. W tym okresie zostaje on poddany wstępnym badaniom lekarskim, zabiegom sanitarnym oraz wstępnym badaniom osobopoznawczym. Zostaje także zapoznany z podstawowymi aktami prawnymi dotyczącymi wykonywania kary pozbawienia wolności, jak również porządkiem wewnętrznym aresztu śledczego. Należy ocenić, że są to czynności rutynowe, mające przystosować osadzonego do warunków więziennych. Raczej trudno doszukać się w nich zindywidualizowanych oddziaływań penitencjarnych. Mam także poważne wątpliwości, czy wyrazem zasady indywidualizacji oddziaływań na skazanego jest wskazana w art. 100 k.k.w. możliwość odbywania kary we właściwym zakładzie karnym położonym, w miarę możliwości, najbliżej miejsca zamieszkania skazanego. Z indywiduali-

Nowa Kodyfikacja Prawa Karnego 54, 2019

(C) for this edition by CNS 
zacją w postępowaniu z nowo osadzonym należy jednak łączyć badania psychologiczne lub psychiatryczne, a także badania osobopoznawcze. Jak zatem widać, wskazane czynności o różnym charakterze w oddziale 13 pomieszano.

Odnośnie do rozwiązań unormowanych w oddziale 3 kodeksu karnego wykonawczego, wpisujących się w zasadę oddziaływań zindywidualizowanych w zakładzie karnym po przyjęciu do niego osoby skazanej na bezwzględną karę pozbawienia wolności, znalazły się one w dalszych częściach tego oddziału. Wynika to z logiki jego redakcji, adekwatnej do chronologii postępowania ze skazanym. Unormowania te odnoszą się więc do czynności podejmowanych w zakładzie karnym po etapie wstępnym, przejściowym. Moim zdaniem tylko one mogą być analizowane jako czynności sensu stricto zindywidualizowane, a więc dostosowane do kryminologicznej diagnozy konkretnego skazanego oraz prognozy jego zachowania w zakładzie karnym. Chodzi tu więc o taki dobór metod i środków, a także możliwości systemowych oddziaływania na skazanego, który dostosowywałby je do jego cech osobowych i osobowościowych. Te ostatnie są bowiem indywidualne, zróżnicowane i niepowtarzalne, takie więc powinny być adekwatne do nich oddziaływania penitencjarne.

W zakresie możliwości systemowych kodeks karny wykonawczy wskazuje zróżnicowanie zakładów karnych na rodzaje i typy. Unormowania w tym zakresie rozrzucone są jednak po równych częściach kodeksu. Ogólne unormowania, określające rodzaje i typy zakładów karnych, ich podległość, tworzenie i znoszenie, a także sposób zarządzania i nadzoru zawarte są w art. 68-73 k.k.w., a więc w oddziale 2 Zakłady karne. Wskazane przepisy dość trudno uznać za wyraz zasady indywidualizacji wykonania kary pozbawienia wolności w rozumieniu metodyki postepowania w tym zakresie. Regulują raczej kwestie ustrojowe, konstytutywne systemu penitencjarnego co do tworzących go struktur. Sa zatem komplementarne do ustawy z dnia 9 kwietnia 2010 roku o Służbie Więziennej, która normuje między innymi kwestie strukturalne służby, stanowiąc, że jej jednostkami organizacyjnymi są zakłady karne i areszty śledcze (por. art. 8 ust. 1 pkt 3$)^{23}$.

23 Dz.U. 2010 Nr 79, poz. 523.

Nowa Kodyfikacja Prawa Karnego 54, 2019

(C) for this edition by CNS 
Z kolei rozwiązania szczegółowe, określające cechy poszczególnych rodzajów i typów zakładów karnych, ich organizację, zasady funkcjonowania, a także kategorie osób osadzanych w nich, ujęto w osobnym oddziale 3 Wykonanie kary i jej indywidualizacja (por. art. 84-92 k.k.w.). Trudno więc jednoznacznie ocenić, czy i w jakim stopniu są wyrazem indywidualizacji penitencjarnej w rozumieniu metodyki oddziaływania na skazanych. Wątpliwości tu wzmaga uregulowanie kwestii ustrojowych i proceduralnych w jednym miejscu. Zawarte w nim przepisy wydają się dość zróżnicowane co do kwestii, które normują.

Niemniej jednak należy zauważyć wzajemną zależność między zasadą indywidualnego traktowania skazanych a typem zakładu karnego, w którym odbywa karę pozbawienia wolności. Zakres uprawnień skazanych w poszczególnych typach zakładów uzależniony jest od indywidualnych postępów w procesie ich resocjalizacji. Na katalog tych uprawnień, które okresowo mogą być zwiększane lub ograniczane, wpływa indywidualna ocena zachowania skazanych. W zależności od wyników tej oceny, zgodnie z zasadą wolnej progresji, mogą oni stopniowo ,przechodzić” z zakładów karnego typu zamkniętego do typu półotwartego, z półotwartego zaś do otwartego.

Jako wyraz indywidualizacji postępowania, chociaż także o charakterze systemowym, można uznać odmienność postępowania penitencjarnego wobec różnych kategorii skazanych (na przykład młodocianych, kobiet, osób chorych i niepełnosprawnych, skazanych poddawanych terapii, skazanych szczególnie niebezpiecznych). Jest ona też widoczna w odmiennym sposobie traktowania skazanych zatrudnionych oraz skazanych uczniów.

Jeśliby zatem, korzystając z wszystkich uwag tu sformułowanych, pokusić się na koniec o ogólną ocenę unormowań kodeksu karnego wykonawczego w zakresie koherencji zasady indywidualizacji w postępowaniu penitencjarnym do systemów wykonawczych, to trzeba stwierdzić, że jest ona zróżnicowana. Zgodzić się jednak należy z dość powszechną opinią, iż najpełniej jest ona realizowana $\mathrm{w}$ ramach systemu programowanego oddziaływania.

System programowanego oddziaływania zakłada $\mathrm{z}$ jednej strony aktywną pracę wychowawcy z konkretnym osadzonym, mającą na celu korekcję jego osobowości, z drugiej zaś równie aktywny jego współ-

Nowa Kodyfikacja Prawa Karnego 54, 2019

(C) for this edition by CNS 
udział w opracowaniu i realizacji indywidualnego programu oddziaływania. W programie tym określa się metody i środki najbardziej właściwe z punktu widzenia potrzeb korekcyjnych skazanego ${ }^{24}$.

$\mathrm{Z}$ propozycją stosowania programu występuje $\mathrm{z}$ reguły personel penitencjarny, który dzięki badaniom osobopoznawczym oraz przeprowadzonej diagnozie, dysponuje odpowiednią wiedzą o potrzebach konkretnego skazanego, jego cechach i właściwościach. Nie ma jednak żadnych przeszkód, aby stroną równie aktywną był sam skazany, który może przedstawić swoje problemy i proponować sposoby ich rozwiązywania w ramach indywidualnego programu oddziaływania ${ }^{25}$.

Indywidualny program oddziaływania obejmuje elementy wskazane w art. $95 \S 2$ k.k.w. Są to: rodzaj zatrudnienia i nauczania skazanego, jego kontakty z rodziną oraz innymi osobami bliskimi, sposób wykorzystywania czasu wolnego, możliwość wywiązywania się z ciążących na nim obowiązków, ponadto inne przedsięwzięcia konieczne do przygotowania jego powrotu do społeczeństwa ${ }^{26}$.

Elementy programu wskazuje również rozporządzenie w sprawie sposobu prowadzenia oddziaływań penitencjarnych w zakładach karnych i aresztach śledczych ${ }^{27}$ (por. $§ 14$ ust. 3). Zgodnie z nim chodzi tu o zakres prowadzonych oddziaływań, możliwe do realizacji w warunkach zakładu ich cele, ponadto wynikające z nich szczegółowe zadania nałożone na skazanego wraz z terminami ich realizacji, wreszcie kryteria wywiązywania się z zadań określonych $\mathrm{w}$ indywidualnym programie oddziaływania.

K. Sitnik, opisując procedurę przygotowania indywidualnego programu oddziaływania, wskazuje, że obejmuje ona kilka etapów. Pierwszy z nich to zebranie informacji o skazanym. Ważne tu jest zwłaszcza

${ }^{24}$ M. Bramska, M. Kiryluk, Realizacja systemu programowanego oddziaływania w toku wykonywania kary pozbawienia wolności, „Przegląd Więziennictwa Polskiego" 2002, nr 3, s. 33.

25 T. Szymanowski, op. cit., s. 219.

${ }^{26} \mathrm{~W}$ redakcji przepisu użyto sformułowania: ,w programach oddziaływania ustala się zwłaszcza". Tak więc katalog środków oddziaływania nie jest zamknięty.

27 Rozporządzenie Ministra Sprawiedliwości z dnia 14 sierpnia 2003 roku w sprawie sposobów prowadzenia oddziaływań penitencjarnych w zakładach karnych i aresztach śledczych, Dz.U. Nr 151, poz. 1469.

Nowa Kodyfikacja Prawa Karnego 54, 2019

(C) for this edition by CNS 
przeprowadzenie badań osobopoznawczych ${ }^{28}$ oraz analiza treści zapisów z rozmów przeprowadzonych ze skazanym, a także innych notatek dotyczących jego osoby ( $\$ 14$ ust. 1 rozporządzenia w sprawie sposobów prowadzenia oddziaływań penitencjarnych) ${ }^{29}$.

Kolejnym etapem ustalenia indywidualnego programu oddziaływań jest opracowanie diagnozy. Obejmuje ona opis oraz wyjaśnienie przyczyn nieprzestrzegania przez skazanego norm prawnych lub niedostosowania społecznego, opis funkcjonowania skazanego w kontaktach społecznych, a także jego podstawowych problemów (por. § 14 ust. 2 rozporządzenia w sprawie sposobów prowadzenia oddziaływań penitencjarnych).

Ostatni etap obejmuje zapoznanie skazanego z treścią diagnozy. Wychowawca informuje go o sposobie i terminie opracowania indywidualnego programu oddziaływania w celu uzyskania jego zgody na współudział w tworzeniu tego programu, następnie zaś jego wykonaniu.

Należy jeszcze dodać, że zgodnie z $\S 14$ ust. 6 powołanego rozporządzenia indywidualny program oddziaływania penitencjarnego opracowuje się niezwłocznie, nie później jednak niż w terminie 30 dni od osadzenia skazanego w zakładzie karnym.

Jak zatem widać, system programowanego oddziaływania stwarza znacznie lepsze warunki do realizacji zasady indywidualizacji w wykonaniu kary niż system zwykły czy terapeutyczny. Jego najważniejszym elementem jest bowiem indywidualny program oddziaływań, którego w dwóch pozostałych systemach nie sporządza się (por. 96 i 98 k.k.w.).

$\mathrm{Na}$ koniec, podsumowując wszystko, co zawarto w tym artykule na temat indywidualizacji penitencjarnej w kodeksie karnym wykonawczym, kilka wniosków ogólniejszych.

1. W kodeksie karnym wykonawczym dostrzeżono konieczność różnicowania form, środków oraz metod oddziaływań penitencjarnych. Wprost o indywidualizacji oddziaływań mówi on jednak tylko w oddziale 3. Jego tytuł wydaje się sformułowany błędnie, można go bowiem odczytać jako indywidualizacja kary, nie zaś postępowania ze skazanym. Utrudnia to dość istotnie jednoznaczną ocenę sposobu legislacji rozwiązań mających

28 Szeroko na ich temat L. Tyszkiewicz w pracy Badania osobopoznawcze w prawie karnym, Warszawa 1975.

29 K. Sitnik, Indywidualny program wykonywania kary pozbawienia wolności jako podstawa systemu programowanego oddziaływania, NKPK 27, 2011.

Nowa Kodyfikacja Prawa Karnego 54, 2019

(C) for this edition by CNS 
na celu realizację zasady indywidualizacji wykonania kary pozbawienia wolności w zakładzie karnym.

2. Mimo to trzeba zgodzić się z opinią, że podstawowymi elementami indywidualizacji postępowania ze skazanym są: różne rodzaje i typy zakładów karnych, systemy wykonania kary pozbawienia wolności, a także odpowiednie rozmieszczanie w nich, klasyfikowanie do nich skazanych na podstawie zindywidualizowanych badań osobopoznawczych. Indywidualizacja ta ma jednak charakter instytucjonalny.

3. Uwidacznia się pewna sprzeczność w logice zakładającej łączenie oddziaływań na określone grupy skazanych w ramach wystandaryzowanych systemów wykonawczych z indywidualnymi programami oddziaływań na konkretne osoby. Sprzeczność tę łagodzi konstrukcja systemu programowanego oddziaływania, która przewiduje dwustopniowość indywidualizacji oddziaływań. Pierwszy stopień obejmuje kwalifikowanie skazanych do określonego systemu, a więc pewną ich selekcję. Istotą drugiego, którym obejmuje się wcześniej tak dobraną grupę skazanych, jest opracowanie dla każdej z osób z tej grupy indywidualnego programu oddziaływań.

Takiej możliwości w systemie zwykłym oraz terapeutycznym nie ma. Zasada indywidualizacji wykonania kary jest więc w nich widoczna wyraźnie słabiej.

\section{Bibliografia}

Bramska M., Kiryluk M., Realizacja systemu programowanego oddziatywania w toku wykonywania kary pozbawienia wolności, „Przegląd Więziennictwa Polskiego” 2002, nr 3.

Hołda J., Hołda Z., Prawo karne wykonawcze, Kraków 2004.

Hołda Z., Postulski K., Kodeks karny wykonawczy. Komentarz, Gdańsk 2005.

Kodeks karny wykonawczy. Komentarz, red. J. Lachowski, Warszawa 2016.

Lelental S., Kodeks karny wykonawczy. Komentarz, Warszawa 2013, 2017.

Lelental S., Prawo karne wykonawcze, Warszawa 1990.

Pawela S., Kodeks karny wykonawczy. Praktyczny komentarz z indeksem rzeczowym, Warszawa 1999.

Pawela S., Prawo karne wykonawcze, Kraków 2003.

Sitnik K., Indywidualny program wykonywania kary pozbawienia wolności jako podstawa systemu programowanego oddziaływania, NKPK 27, 2011.

Słownik języka polskiego, t. 1, red. M. Szymczak, Warszawa 2010.

Nowa Kodyfikacja Prawa Karnego 54, 2019

(C) for this edition by CNS 
System penitencjarny i postpenitencjarny $w$ Polsce, red. T. Bulenda, R. Musidłowski, Warszawa 2003.

Szymanowski T., Polityka penitencjarna w Polsce wspótczesnej, [w:] System prawa karnego, red. A. Marek, Warszawa 2010.

Wierzbicki P., Indywidualizacja penitencjarna w Polsce, Warszawa 1976,

Wzorcowe Reguły Minimalne Organizacji Narodków Zjednoczonych, https://www.rpo. gov.pl/sites/default/files/Reguly_Mandeli.pdf (dostęp: 18.01.2020).

Tyszkiewicz L., Badania osobopoznawcze w prawie karnym, Warszawa 1975.

\section{Individualization and the system in penitentiary proceedings in the light of the Executive Penal Code}

\section{Summary}

The article is devoted to the principle of penitentiary proceedings for individuals during the implementation of imprisonment and its coherence with executive systems. The author analyzes both the concept and the content of this principle. She also discusses how it is articulated in the Executive Penal Code. As a result, the article states that this is institutional individualization. In this context, it considers how individualization is consistent with standardized systems of implementation for punishment. It draws attention to various system definitions in Polish penitentiary literature. It estimates that only the system of "programmed impact" creates full conditions for combining (in practice) the level of the system with the level of the individual, i.e. a particular convict. Finally, it states that the title of Section 3 of the Criminal Code is formulated incorrectly, because it can be read that it is about the individualization of punishment, and not about dealing with the convict. This makes it quite difficult to unequivocally assess the way in which solutions aimed at implementing the principle of individualization of imprisonment in prisons are implemented.

Keywords: individualization, system, punishment, implementation of a sentence, penal institution, executive penal code. 